\title{
The English Influence on Japanese, Indonesian, and Malang Slang Words: a Study of Wakamono Kotoba, Bahasa Gaul, and Slang Malang
}

\author{
Suraida Nurul Oktavia*, Vera Yulianti \\ *Program Studi Bahasa dan Kebudayaan, Universitas Al-Azhar Indonesia, Jakarta, Indonesia \\ e-mail: viawiratmaja1@gmail.com
}

\begin{abstract}
In the characteristics of the morphological formation of Japanese slang words (Wakamono Kotoba), Indonesian slang words (Bahasa Gaul), and Malang slang words (Slang Malang), there is a phenomenon of English influence. The purpose of this study is to examine the morphological characteristics of the English influence on Japanese slang words (Wakamono Kotoba), Indonesian slang words (Bahasa Gaul), and Malang slang words (Slang Malang). The data was collected from Twitter accounts which the users are native Japanese language, native Indonesian language, and native Malang language. The analysis was based on the classification of word-formation categories Akihiko Yonekawa (Yonekawa, 1998). The result of the study shows that the English influence on Japanese slang words is in the category of English borrowing and the combination of Japanese and English. Meanwhile, the English influence on Indonesian slang words and Malang slang words is only in the form of English borrowing.
\end{abstract}

Keywords:

Morphology; Wakamono

kotoba; Bahasa gaul; Slang

malang

Article Info:

First received:

12 August 2021

Available online:

30 Month 2021

\section{PENDAHULUAN}

Tiap bahasa sangat beragam dan memiliki variasinya masing-masing. Chaer dan Agustina membedakan ragam bahasa berdasarkan pada latar belakang seperti segi sosial penuturnya dan penggunaan bahasa tersebut. Variasi bahasa pada segi sosial penuturnya menyangkut pada siapa yang menggunakan bahasa tersebut dan juga semua latar belakang pribadi para penuturnya seperti dari segi kedudukan sosial, jenis kelamin, pendidikan, status ekonomi, ataupun usia daripada si penutur. Sedangkan pada segi penggunaannya dilihat dari bahasa tersebut dipergunakan untuk apa, pada bidang apa, dan bagaimana situasi keformalannya. (Chaer and Agustina 2004).

Variasi bahasa yang sering menjadi tema penelitian dalam linguistik adalah ragam bahasa anak muda. Menurut Wijana, sangat terlihat jelas perbedaan antara bahasa anak muda dan bahasa kelompok sosial lain jika ditinjau dari segi kebahasaannya seperti pada bidang morfologi, fonologi, sintaksis, dan lain-lain. (Wijana 2010).
Ragam bahasa anak muda diciptakan, digunakan, dan juga disebarluaskan umumnya oleh para generasi muda. Karena kreativitas para generasi muda di Jepang, Indonesia, maupun daerah-daerah di Indonesia, ragam bahasa anak muda ini melahirkan banyak kosakata-kosakata baru dengan cara membuat kata-kata baru atau memodifikasi kata yang sudah ada yang sifatnya sangat temporal atau berubah-ubah dari waktu ke waktu. Kosakatakosakata pada ragam bahasa anak muda ini terbentuk dari berbagai macam proses morfologis seperti proses afiksasi, reduplikasi, abreviasi, dan lain-lain (Kridalaksana 1996).

Ragam bahasa anak muda Jepang disebut sebagai wakamono kotoba (若者言葉) [Dictionary Goo , 2021]. Tak hanya di Jepang, Indonesia juga memiliki ragam bahasa anak muda yang biasa kita kenal sebagai Bahasa Gaul (Kridalaksana 2011). Sedangkan di beberapa daerah di Indonesia, juga terdapat Bahasa slang daerah.

Salah satu yang paling terkenal adalah Boso Malangan atau biasa disebut Slang Malang 
(Prayogi 2013). Sama halnya dengan wakamono kotoba dan Bahasa Gaul, Slang Malang ini banyak dikenal dan digunakan oleh anak-anak muda di kota Malang. Bahasa ini sudah menjadi identitas anak-anak muda di kota Malang karena bahasanya yang berbeda, unik, beragam, dan praktis. Boso Malangan ini umum dijadikan sebagai bahasa identitas dan bahasa komersial pada nama produk dan usaha di Malang sejak tahun 90-an. Hingga saat ini kosakata-kosakata Slang Malang ini masih terus berkembang dan mengalami penambahan kosakata-kosakata baru (Yannuar 2019). Menurut Widodo, pada bukunya yang berjudul Malang Tempoe Doeloe, Slang Malang ini dahulunya diciptakan oleh kelompok Gerilya Rakyat Kota (GRK) yang berjuang di sekitar area Malang pada masa penjajahan. Bahasa ini digunakan oleh tentara Republik Indonesia untuk berkomunikasi dengan sesamanya agar tidak diketahui oleh para penjajah (Widodo 2006).Menurut Tom G Hoogervorst, selain bersifat rahasia, bahasa para anak muda biasanya digunakan untuk upaya pendekatan antar sesamanya dan untuk menyebutkan kata-kata tabu yang berkenaan dengan seksual, narkotika, kejahatan, dan sebagainya [Hoogervorst G, 2014].

Pada proses pembentukan dalam ragam bahasa anak muda ini pun, Wakamono Kotoba memiliki karakteristiknya sendiri seperti memendekkan unsur kata atau kalimat, membalikkan urutan-urutan unsur-unsur kata, membuat verba dengan menambah silabel 'ru', dan 'tte', dan mengungkapkan sesuatu dengan mengambil karakteristik manusia (Tanaka and Tanaka 1997). Ragam bahasa anak muda di Indonesia adalah ragam bahasa tidak resmi yang muncul pada akhir tahun 1980-an (Kridalaksana 2011). Ragam Bahasa Gaul ini memiliki ciri khas yaitu cenderung memendekkan/menyingkat kata yang agak panjang, namun Bahasa Gaul yang berkembang belakangan ini sering tidak dapat terdeteksi proses morfologisnya karena cenderung tidak beraturan dan tidak mengikuti kaidah-kaidah linguistik (Mastuti 2008).

Berikut beberapa contoh karakteristik wakamono kotoba, Bahasa Gaul, dan Slang Malang:

\section{a) Zuttomo (ズッ友)}

(Alisyahbana 2020)
Kata ini termasuk pada contoh karakteristik proses morfologis pada wakamono kotoba yaitu proses penggabungan kata. Zuttomo berasal dari frasa 'zutto' dan 'tomo' yang memiliki arti 'teman selamanya'. Kata ini mengalami porses morfologis yang mana dua kata dari frasa ini yaitu kata zutto mengalami pelesapan pada silabel akhir dan menyisakan silabel awal yaitu 'zut', sedangkan pada kata kedua mengalami pelesapan di dua silabel pada kata terakhir dan menyisakan silabel awal yaitu "tomo", lalu dua kata ini digabungkan menjadi satu frasa yaitu "zuttomo".

b) Karena perjuangan harus ada pengorbanannya gan! \#harus \#Strong terus:).

(Swandy 2017)

Gan berasal dari kata 'juragan' yang pada kalimat ini bisa diartikan sebagai sebuah panggilan keakraban kepada orang lain di sosial media atau forum online. Kata 'gan' ini mengalami proses morfologis yaitu melesapkan dua silabel awal pada kata tersebut dan menyisakan silabel akhir yaitu "gan".

c) Rek, numpak libom ae, enak!

Terjemahan: 'Teman-teman, lebih enak naik mobil saja!'

(Prayogi 2013)

Libom berasal dari kata 'mobil' yang telah mengalami proses morfologis pembalikan fonem. Kata mobil mengalami proses pembalikan total karena pada kata ini semua fonem dibalik seperti membacanya dari belakang. Proses ini adalah salah satu ciri khas dari Slang Malang yaitu membolak-balikkan fonem pada tiap-tiap kata.

Akihiko Yonekawa (Yonekawa 1998) menngungkapkan bahwa terdapat 13 proses pembentukan Wakamono Kotoba. Dari tiga belas proses pembentukan tersebut, terdapat dua proses yang mendapat pengaruh dari bahsa Inggris. Dua kategori proses tersebut adalah 'Peminjaman bahasa Asing' dan ' Gabungan Bahasa Lokal dan Bahasa Inggris'.

Pada kategori 'Peminjaman Bahasa Asing' pengaruh berbagai Bahasa asing masuk dan diserap sepenuhnya menjadi kosakata Bahasa setempat. Pada Wakamono Kotoba, Bahasa Inggris, bahasa Prancis, dan bahasa Jerman termasuk ke dalam bahasa yang cukup sering digunakan untuk membentuk Wakamono Kotoba. 
Berikut adalah salah satu contoh dari proses tersebut:

d. Wanchan (ワンチャン)

(Alisyahbana 2020)

Pada data (d) kata wanchan ini adalah kata serapan dari bahasa Inggris yaitu one chance yang memiliki arti yaitu satu kesempatan. Sedangkan pada kategori kedua, yaitu gabungan bahasa lokal dan Bahasa Inggris, bahaas anak muda terbentuk dengan menggabungkan keduanya menjadi kata baru yang digunakan anak muda. Berikut adalah contoh kategori ini pada wakamono kotoba:

e. toaruzi (タオル地) $\rightarrow$ towel cloth

(Alisyahbana 2020)

Pada data (e), kata toaruzi merupakan gabungan dari bahasa Jepang dari kata $z i$ dan bahasa Inggris pada kata toaru yang memiliki arti yaitu kain handuk. Pada proses ini, pembentukan katanya ditulis dengan menggabungkan antara bahasa Jepang (hurufhuruf Jepang) dan bahasa inggris (romaji).

Dari contoh ragam wakamono kotoba, Bahasa Gaul, dan Slang Malang di atas, terlihat bahwa terdapat berbagai variasi proses morfologis dari ketiga bahasa tersebut. Adapun variasi proses morfologis yang banyak ditemui pada penggunaan Bahasa di media sosial adalah proses morfologis Bahasa anak muda yang dipengaruhi Bahasa Ingggris. Pengaruh Bahasa Inggris ini juga ditemui pada Bahasa Slang Indonesia, Wakamono Kotoba, dan Slang Malang (Hoogervorst 2014; Stanlaw 2014; Wijana 2012).

Umumnya pengaruh Bahasa Inggris dalam bahasa anak muda di berbagai negara dan wilayah, lebih banyak dikaji dari pendekatan semantik (Matsumoto et al. 2011; Rezeki and Sagala 2019; Slotta 2016). Dapat dipertimbangkan yang dapat menjadi alas an kecenderungan ini adalah karena karakteristik bahasa anak muda sendiri yang sulit dimengerti sehingga multitafsir dan menarik untuk dikaji dari kajian semantic.

Namun, sebenanrya kajian secara morfologis tentang pengaruh bahasa Inggris terhadap suatu bahasa berpontensi memberikan kontribusi untuk dunia konten kreatif. Penguasaan kajian morfologi akan memberikan ide-ide dalam penamaan produk baru yang banyak dipakai anak muda dengan menggunakan variasi pengaruh bahasa Inggris sehingga promosi produk tersebut akan lebih bersifat mendunia.

Oleh karena itu dalam penelitian ini telah diteliti pengaruh bahasa Inggris terhadap wakamiono kotoba, bahasa slang Indonesia, dan boso Malang dari segi pembentukan morfologis. Selain diharapkann bermanfaat bagi penamaan produk-produk Jepang, Indonesia, dan lokal Malang, juga diharapkan pemelajar bahasa asing dapat menguasai bahasa Indonesia dan bahasa daerah dengan baik seperti halnya penguasaan bahasa asing (bahasa Jepang).

\section{METODE PENELITIAN}

Data yang diperoleh adalah data yang diambil dari media sosial twitter bergenre anak muda dengan ketertarikan pada dunia entertaiment (penyuka musik, Kpop, Jpop, film, dan lain-lain). Para pemilik akunnya juga termasuk penutur jati bahasa Jepang, bahasa Indonesia dan boso Malangan. Penelitian ini berfokus pada data yang menunjukkan proses morfologis karakteristik wakamono kotoba, Bahasa Gaul, dan Slang Malang.

\section{HASIL DAN PEMBAHASAN}

Berikut ini disajikan temuan penelitian dan hasil analisis data dari masing-masing temuan penelitian.

\section{Peminjaman Bahasa Asing}

(1) アルバイト

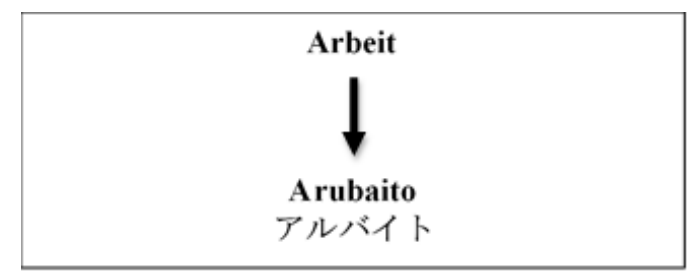

「何をしてたかというと陸送のアルバイト w 倉敷から京都まで無事終了」

Nani o shi teta ka to iu to rikusō no arubaito $w$

Kurashiki kara Kyōto made buji shūryō 
(Twiter@NTFSerror, link :https://bit.ly/3vwNWcO)

Terjemahan:

Apa yang saya lakukan adalah bekerja paruh waktu dengan transportasi darat. Dan selesai dengan selamat dari Kurashiki ke Kyoto.

Situasi :

Pada data (1) diketahui pemilik akun Twitter '@NTFSerror' adalah seorang laki-laki. Tidak diketahui usia pasti dari pemiliki akun ini namun penulis memperkirakan usianya adalah sekitar 22-25 tahun. Dalam cuitannya pada akun @NTFSerror, pemilik akun ini menggunakan kata arubaito untuk memberitahukan bahwa ia sedang bekerja paruh waktu di bagian transportasi darat lengkap dengan foto mobil yang tertera pada cuitannya.

Analisis :

Pada data (1) ini, kata アルバイト(arubaito) merupakan kata serapan yang berasal dari bahasa Jerman yaitu kata arbeit. Menurut kamus [Dict.com, 2021], kata arbeit memiliki arti kerja, gawai, atau pekerjaan. Kata arubaitoini tercatat sejarah muncul pada awal jaman Meiji dan masih tetap populer di kalangan anak muda hingga sekarang. Berikut adalah proses morfologis dari kata アルバイト(arubaito):

Pada proses morfologi dari kata アルバイト (arubaito) ini, kata arubaito masuk ke dalam kategori peminjaman bahasa asing karena kata tersebut diserap dari bahasa Jerman yang memiliki arti yaitu bekerja. Sampai saat inipun kata arubaito masih sangat sering dipakai anak muda Jepang yang melakukan part-time. Tak jarang kata ini juga disingkat menjadi baito atau baito suru.

(2) ドンマイ

\begin{tabular}{|c|}
\hline Don't Mind \\
$\downarrow$ \\
Don Mai \\
ドンマイ \\
\hline
\end{tabular}

「よくある事だよね、ドンマイ！笑」

Yoku aru kotoda yo ne, Don Mai! Emi

(Twitter@takeeee507, link :https://bit.ly/2SkNRul )

Terjemahan:

Itu hal yang biasa terjadi kok, jangan terlalu dipikirkan!

Situasi :

Pada data (2) diketahui pemilik akun Twitter ‘@takeeee507' adalah seorang laki-laki. Tidak diketahui pasti usia dari pemilik akun ini namun penulis memperkirakan usianya adalah sekitar 21-25 tahun. Dalam cuitannya pada akun '@takeeee507', pemilik akun ini menggunakan kata donmai untuk mengutip cuitan dari akun jualan yang sedang meminta maaf atas kekurangannya dalam melayani pembeli.

Analisis :

Pada data (2) ini, kata ドンマイ (donmai) merupakan kata serapan yang berasal dari bahasa Inggris. Berikut adalah proses morfologis dari kata ドンマイ(donmai):

Pada proses morfologi dari kata ドンマイ (donmai) ini, kata donmai masuk ke dalam kategori peminjaman bahasa asing karena kata tersebut diserap dari bahasa Inggris yang memiliki makna tidak papa, tidak penting atau tak usah dipikirkan.

(3) なう

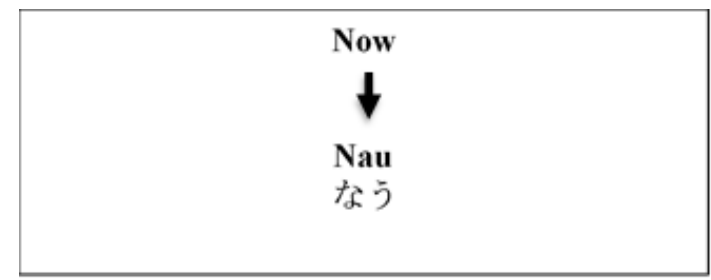

「彼女なうに使って欲しいですき)」

Kanojo nau ni tsukatte hoshii desu.

(Twitter: @ai_uehara_ex, link: https://bit.ly/3g9h44V) 
Terjemahan:

Aku ingin dia menggunakannnya sekarang.

Situasi :

Pada data (3) diketahui pemilik akun Twitter ‘@ai_uehara_ex' adalah seorang perempuan. Tidak diketahui pasti usia dari pemilik akun ini namun penulis memperkirakan usianya adalah sekitar 21-25 tahun. Dalam cuitannya pada akun "@ai_uehara_ex, pemilik akun ini menggunakan kata nauuntuk menjelaskan bahwa dia menginginkan seorang perempuan untuk menggunakan sesuatu itu saat ini juga atau sekarang.

Analisis :

Pada data (3) ini, kata なう(nau)merupakan kata serapan yang berasal dari bahasa Inggris yaitu kata 'now'. Kata 'now' sendiri menurut kamus [Merriam Webster, 2021] memiliki arti yaitu 'saat ini' atau 'sekarang'. Berikut adalah proses morfologis dari kata なう (nau):

Pada proses morfologi dari kata なう (nau) ini, kata naumasuk ke dalam kategori peminjaman bahasa asing karena kata tersebut diserap dari bahasa Inggris yang memiliki makna sekarang atau saat ini.

Menurut Akihiko Yonekawa (Yonekawa 1998), kategori peminjaman bahasa asing ini memiliki ciri-ciri yaitu proses pembentukan katanya menyerap dari bahasa-bahasa asing seperti bahasa Inggris, bahasa Prancis, bahasa China, bahasa Jerman, dan lain-lain. Proses pembentukannya pun hanya melalui tahap penyerapan dari bahasa asing lalu dibahasakan atau dibunyikan ke dalam bahasa Jepang dengan menggunakan aksara Jepang. Dan pada data di atas yaitu data (1) アルバイト(arubaito), data (2) ドンマイ(donmai), dan data (3) なう (nau) telah mengalami proses peminjaman bahasa asing yang kata dasarnya dipinjam dari bahasa Jerman dan bahasa Inggris.

\section{(4) Kalem}

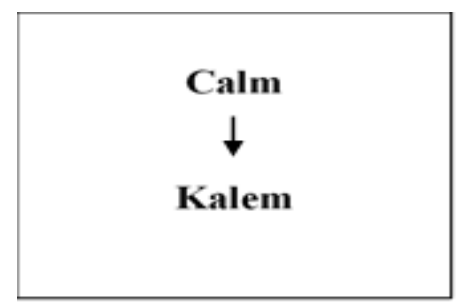

[Kalem bro, doi cuma mancing, umpan nya jangan lu makan mulu kaya yang udah-udah tar alkohol lagi dah]

(Twitter@gue_andhika, link :https://bit.ly/3eh70WM )

Terjemahan baku:

Kalem bro, dia cuman mancing, umpannya jangan kamu makan terus seperti yang sudahsudah, nanti alkohol lagi deh.

Situasi :

Pada data (4) ini diketahui pemilik akun '@gue_andhika' adalah seorang laki-laki dengan perkiraan usia sekitar umur 20-25 tahun berdasarkan pada cuitan-cuitannya. Dalam cuitan pada akun '@gue_andhika', pemilik akun menggunakan kata kalem untuk mengomentari postingan dari seseorang.

Analisis :

Dalam data (4) kalem, kata kalem merupakan kata serapan dari bahasa Inggris yaitu kata calm. Karena diserap dari kata calm, arti dari kata kalem pun juga sama dengan calm yaitu tenang. Dalam konteks pada data (4), kata kalem ini merujuk kepada pemilik akun yang menyuruh orang yang sedang ada di dalam percakapan dengannya untuk bersikap tenang. Berikut adalah proses morfologis kata kalem:

Pada proses morfologis dari data (4) kalem ini, kata kalem masuk ke dalam kategori peminjaman bahasa asing karena kata kalem diserap dari bahasa Inggris. Untuk proses morfologisnya, kata calm akan menyesuaikan langsung dengan ejaan bahasa Indonesia yaitu silabel/CA/ dibaca /KA/, fonem konsonan /L/ diberi tambahan vokal /E/ menjadi silabel /LE/dan diakhiri dengan konsonan /M/.

Menurut Akihiko Yonekawa (Yonekawa 1998), kategori peminjaman bahasa asing ini memiliki ciri-ciri yaitu proses pembentukan katanya dilakukan dengan menyerap kata dari bahasa asing lalu dilafalkannya sesuai dengan abjad Indonesia. Dan pada data di atas yaitu data (4) kalem telah mengalami proses peminjaman bahasa asing dengan mengambil atau menyerap kata-katanya dari bahasa Inggris. 
(5) Mbois

\begin{tabular}{|c|}
\hline Boyish \\
$=$ \\
Mbois \\
\hline
\end{tabular}

[Asal kon ero rek, foto ktpku paling mbois sak jagat raya.]

(Twitter@deadspideeeyyy, link :https://bit.ly/3ukCzEx )

Terjemahan:

"Asal kalian tahu rek, foto ktpku paling mbois sejagat raya."

Situasi :

Pada data (5) ini diketahui pemiliknya adalah seorang laki-laki dengan perkiraan usia sekitar umur 20-25 tahun berdasarkan pada cuitancuitannya. Dalam cuitan pada akun @deadspideeeyyy, pemilik akun menggunakan kata mbois memberitahukan kepada semua orang bahwa foto ktpnya adalah yang terbaik.

Analisis :

Dalam data (5) ini, kata mbois berasal dari kata pada bahasa Inggris yaitu boyish yang artinya adalah kelaki-lakian. Secara harfiah, makna mbois bentuk penampilan atau cara berpakaian seseorang yang sangat keren. Namun saat ini, seiring berjalannya waktu, kata mbois ini mengalami perluasan makna. Di beberapa konteks kalimat, kata ini bisa berarti sebagai keren, bagus, baik, atau cocok. Dan berikut adalah proses morfologis dari data mbois:

Pada proses morfologisnya, kata mbois ini masuk ke dalam kategori peminjaman bahasa asing karena mbois sendiri diserap dari bahasa Inggris yaitu dari kata boyish. Setelah kata diserap dari kata boyish lalu disesuaikan dengan pelafalan pada boso Malangan sehingga kata boyish bisa berbunyi seperti boso Jowo Malangan.

Menurut Akihiko Yonekawa (Yonekawa 1998), kategori peminjaman bahasa asingini memiliki ciri-ciri yaitu proses pembentukan katanya dilakukan dengan menyerap kata dari bahasa asing lalu dilafalkannya sesuai dengan abjad Indonesia. Dan pada data di atas yaitu data (5) mbois telah mengalami proses peminjaman bahasa asing dengan mengambil atau menyerap kata-katanya dari bahasa Inggris dan pelafalannya pun mengikuti pelafalan orang Jawa.

\section{Gabungan bahasa Jepang dan Bahasa Inggris}

\section{(6) ありが thanks}

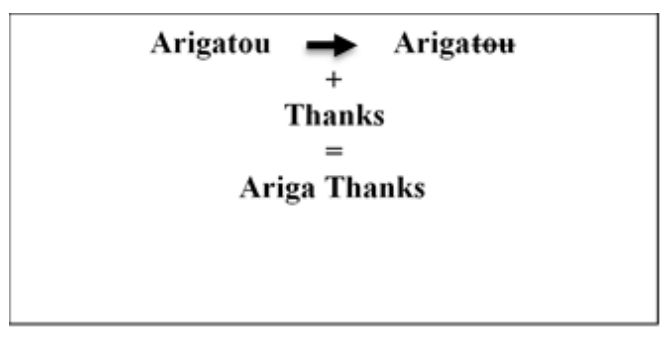

「\#みこなま

皆さまおつみこ〜

GTA で逃げ切る企画初めてリアタイできた - !

めっちゃ草だった歌の途中で悲鳴くるのマジ ですこエリート 35P(or35P オルタ)の行動には いつも笑わせてもらってます、ありが Thanks ござい much」

\#Mikonama

minasama otsu miko GTA de nigekiru kikaku hajimete Ria Tai de kita-! Metcha kusadatta uta no tochū de himei kuru no majidesu ko erìto 35 P (or 35 $P$ oruta) no kōdōni wa itsumo warawa sete morattemasu, ari ga Thanks gozai much

(Twitter@iIh1nT9XZcjeb3X, link :https://bit.ly/3ehbJry)

Terjemahan:

\#Miko Nama

Semuanya Otsumiko

Rencana untuk melarikan diri dengan GTA Saya bisa mengikat ulang untuk pertama kalinya! Saya benar-benar tahu apa yang harus saya lakukan. Benar-benar berteriak di tengah 
lagu. Saya selalu menertawakan aksi elite 35P (atau alternator 35P), terima kasih banyak.

\section{Situasi :}

Pada data (6) diketahui pemilik aku Twitter '@iIh1nT9XZcjeb3X' adalah seorang laki-laki seperti yang tertera pada akunnya. Tidak diketahui usia pasti dari pemiliki akun ini namun penulis memperkirakan usianya adalah sekitar 20-25 tahun. Dalam cuitannya pada akun '@iIh1nT9XZcjeb3X', pemilik akun ini menggunakan kata arigathanksuntuk mengucapkan terima kasih pada orang-orang yang telah menyimak pengalaman pribadi yang dia posting pada akun Twiternya.

Analisis :

Pada data (6) ini, kata ありが thanks (arigathanks) merupakan gabungan dari bahasa Jepang dan bahasa Inggris yang sangat populer di kalangan remaja-remaja di Jepang. Kata ini merupakan gabungan dari kata ありがとう (arigatou) yang menurut kamus [Dictionary Goo, 2021] berarti ungkapan terima kasih dan kata thanksyang memiliki arti ucapan kata terima kasih juga. Berikut adalah proses morfologis dari kata ありが thanks:

Pada proses morfologi dari kata ありが thanks ini, proses awalnya adalah dengan melesapkan morfem keempat, dan kelima yaitu morfem "to" dan "u". Lalu setelah mengalami pelesapan, morfem yang dikekalkan yaitu morfem "a", "ri", dan "ga" digabungkan dengan kata thanksyang akhirnya membentuk kata arigathanks yang memiliki arti sebagai ucapan terima kasih.

\section{(7) sorry ません}

\begin{tabular}{c} 
Sorry \\
Sumimasen $\stackrel{+}{\rightarrow}$ Stmimasen \\
\hline
\end{tabular}

$$
\text { 「船長。。ごめんな Sorry ませんねー :'^)」 }
$$

Sencou, gomenna sorrymansen nee

(Twitter

@ BiscottiLoud, link: https://bit.ly/33cl4uf)
Terjemahan:

Kapten, saya sangat sangat meminta maaf ya.

Situasi :

Pada data (7) diketahui pemilik akun Twitter '@BiscottiLoud' adalah seorang laki-laki. Tidak diketahui usia pasti dari pemiliki akun ini namun penulis memperkirakan usianya adalah sekitar 20-25 tahun. Dalam cuitannya pada akun @BiscottiLoud, pemilik akun ini menggunakan kata sorrymasen untuk meminta maaf kepada kaptennya.

Analisis :

Pada data (7) ini, kata sorry ません (sorrymasen) merupakan gabungan dari bahasa Inggris dan bahasa Jepang yang sangat populer di kalangan remaja-remaja di Jepang. Kata ini merupakan gabungan dari kata sorry yang berarti ungkapan maaf dan kata sumimasenyang pada kamus [Dictionary Goo, 2021] memiliki arti 'maaf' atau 'permisi'. Berikut adalah proses morfologis dari kata sorry ません (sorrymasen):

Awal dari proses morfologi dari data (7) sorry ません (sorrymasen) ini adalah dengan melesapkan silabel pertama dan kedua yaitu silabel "su" dan "mi". Setelah mengalami pelesapan, silabel yang dikekalkan yaitu silabel "ma" dan "sen" digabungkan dengan kata sorry yang akhirnya membentuk kata sorrymasen yang memiliki makna yang sama yaitu sebagai ucapan permintaan maaf.

Menurut Akihiko Yonekawa (Yonekawa 1998), kategori gabungan bahasa Jepang dan bahasa Inggris memiliki ciri-ciri yaitu pembentukan katanya menggabungkan antara bahasa Jepang (aksara Jepang) dengan bahasa Inggris (romaji). Sedangkan data yang masuk ke dalam ciri-ciri teori Akihiko Yonekawa antara lain adalah data (6) ありが thanks yang merupakan gabungan dari dua kata dengan bahasa yang berbeda yang terlebih dahulu mengalami pelesapan pada silabel-silabel akhir pada dua kata tersebut lalu silabel yang dikekalkan kemudian digabungkan menjadi satu kata. Lalu pada data (7) Sorry ません juga merupakan gabungan dari dua kata dengan bahasa yang berbeda yang terlebih dahulu mengalami pelesapan pada silabel awal pada kata kedua (sumimasen) lalu setelah itu baru digabungkan menjadi satu kata. 
Oleh karena itu, maka dapat disimpulkan bahwa kategori pada Wakamono Kotoba yang mengalami penggabungan antara bahasa Jepang dan bahasa Inggris memiliki ciri-ciri yaitu menggabungkan bahasa Jepang dengan bahasa Inggris yang memiliki makna yang sama. Lalu ciri-ciri selanjutnya adalah kata mengalami pelesapan terlebih dahulu baik pelesapan pada morfem awal atau morfem akhir pada tiap-tiap kata sebelum mengalami proses penggabungan kata.

\section{KESIMPULAN}

Kesimpulan dari karakteristik pengaruh bahasa Inggris pada tiga bahasa ini adalah pada proses pembentukan kata pada wakamono kotoba terjadi pada dua karakteristik yaitu pada peminjaman bahasa Inggris dan kategori campuran bahasa Jepang dan bahasa Inggris, sedangkan pada bahasa gaul dan slang malang hanya terjadi proses yaitu peminjaman bahasa Asing yaitu bahasa Inggris.

\section{UCAPAN TERIMA KASIH}

Peneliti mengucapkan terima kasih kepada Universitas Al Azhar Indonesia atas dukungan dana untuk presentasi hasil penelitian ini pada seminar $3^{\text {rd }}$ International Conference on Japanese Studies, Language, and Education 2021.

\section{DAFTAR PUSTAKA}

Alisyahbana, M. F. 2020. Analisis Pembentukan Wakamono Kotoba Dalam Media Sosial Twitter. Hikari, 4 (2), 2020. [Tersedia: https://jurnalmahasiswa.unesa.ac.id/index. php/hikari/article/view/36190/32172].

Chaer, A., \& Agustina, L. 2004. Sosiolinguistik: Perkenalan Awal. Jakarta: PT Rineka Cipta.

Hoogervorst, T. G. 2014. Youth Culture and Urban Pride: The Sociolinguistics of East Javanese Slang. Wacana, 15 (1), pp. 104-31.

Kridalaksana, H. 1996. Pembentukan Kata Dalam Bahasa Indonesia. (Edisi Kedua). Jakarta: Gramedia Pustaka Utama.

Kridalaksana, H. 2011. Kamus Linguistik (Edisi Keempat). Jakarta: Gramedia Pustaka
Utama.

Mastuti, I. 2008. Bahasa Baku vs. Bahasa Gaul. Jakarta: Hi-Fest Pub.

Matsumoto, K., Konishi, Y., Hidemichi, S., Fuji, R. 2011. Analysis of Wakamono Kotoba Emotion Corpus and Its Application in Emotion Estimation. International Journal of Advanced Intelligence 3 (1), pp. 1-24.

Prayogi, I. 2013. Proses Pembentukan Slang Malang. Sasindo 1 (1), .

Rezeki, T. I., Sagala, R. W. 2019. Semantics Analysis of Slang (SAOS) in Social Media of Millennial Generation. KREDO: Jurnal Ilmiah Bahasa dan Sastra 3 (1), pp. 36-46.

Slotta, J. 2016. Slang and the Semantic Sense of Identity. UT Faculty/Researcher Works.

Stanlaw, J. 2014. Some Trends in Japanese Slang. In Global English Slang, Routledge, pp. 172-182.

Swandy, E. 2017. Bahasa Gaul Remaja Dalam Media Sosial Facebook. Jurnal Bastra (Bahasa dan Sastra) 1 (4).

Tanaka, H., Sachiko, T. 1997. Shakai Gengogaku e No Shootai. Society-CultureCommunication, Mineruba Shoboo, Kyoto.

Widodo, D. I. 2006. Malang Tempo Doeloe. Djilid Doea. Malang: Bayumedia Publishing.

Wijana, I. D. P. 2012. The Use of English in Indonesian Adolescent'S Slang. Humaniora 24 (3), pp. 315-327.

Yannuar, N. 2019. Bòsò Walikan Malangan: Structure and Development of a Javanese Reversed. Wacana, 21 (1), pp. 168-175.

Yonekawa, A. 1998. Wakamonogo-o-Kagakusuru. Tokyo: Meiji Shoin. 